\title{
Haemogregarina sp. (Apicomplexa: Haemogregarinidae), Telorchis attenuata (Digenea: Telorchiidae) and Neoechinorhynchus emydis (Acanthocephala: Neoechinorhynchidae) from Map Turtles (Graptemys spp.), in Northcentral Arkansas
}

\author{
C. T. McAllister \\ Eastern Oklahoma State College, cmcallister@se.edu \\ C. R. Bursey \\ Pennsylvania State University \\ H. W. Robison \\ M. B. Connior

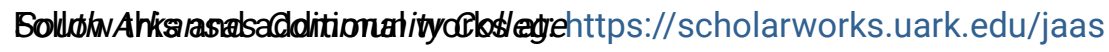 \\ iv. Rastaffotete Animal Studies Commons, and the Zoology Commons \\ Peru State College
}

\section{Recommended Citation}

McAllister, C. T.; Bursey, C. R.; Robison, H. W.; Connior, M. B.; and Barger, M. A. (2014) "Haemogregarina sp. (Apicomplexa: Haemogregarinidae), Telorchis attenuata (Digenea: Telorchiidae) and Neoechinorhynchus emydis (Acanthocephala: Neoechinorhynchidae) from Map Turtles (Graptemys spp.), in Northcentral Arkansas," Journal of the Arkansas Academy of Science: Vol. 68 , Article 28.

DOI: https://doi.org/10.54119/jaas.2014.6823

Available at: https://scholarworks.uark.edu/jaas/vol68/iss1/28

This article is available for use under the Creative Commons license: Attribution-NoDerivatives 4.0 International (CC BY-ND 4.0). Users are able to read, download, copy, print, distribute, search, link to the full texts of these articles, or use them for any other lawful purpose, without asking prior permission from the publisher or the author. This General Note is brought to you for free and open access by ScholarWorks@UARK. It has been accepted for inclusion in Journal of the Arkansas Academy of Science by an authorized editor of ScholarWorks@UARK. For more information, please contact scholar@uark.edu. 


\title{
Haemogregarina sp. (Apicomplexa: Haemogregarinidae), Telorchis attenuata (Digenea: Telorchiidae) and Neoechinorhynchus emydis (Acanthocephala: Neoechinorhynchidae) from Map Turtles (Graptemys spp.), in Northcentral Arkansas
}

\author{
C.T. McAllister ${ }^{1 *}$, C.R. Bursey ${ }^{2}$, H.W. Robison ${ }^{3}$, M.B. Connior ${ }^{4}$, and M.A. Barger ${ }^{5}$ \\ ${ }^{1}$ Science and Mathematics Division, Eastern Oklahoma State College, Idabel, OK 74745 \\ ${ }^{2}$ Department of Biology, Pennsylvania State University, Shenango Campus, Sharon, PA 16146 \\ ${ }^{3} 9717$ Wild Mountain Drive, Sherwood, AR 72120 \\ ${ }^{4}$ Health and Natural Sciences, South Arkansas Community College, El Dorado, AR 71730 \\ ${ }^{5}$ Department of Natural Sciences, Peru State College, Peru, NE 68421
}

*Correspondence: cmcallister@se.edu

Running Title: Haemogregarine, Trematode and Acanthocephalan Records

Little is known about the hematozoa and helminths of turtles of Arkansas. McAllister and King (1980) and McAllister et al. (1995) reported haemogregarines from the red-eared slider, Trachemys scripta elegans and alligator snapping turtle, Macrochelys temminckii, respectively. Fragmentary information is available on acanthocephalans (Ward and Hopkins 1931, Cable and Fisher 1957, Fisher 1960) and a nematode (McAllister et al. 1995). However, the only complete endoparasite survey to date on turtles of the state is that of Rosen and Marquardt (1976) on T. s. elegans. It is obvious that more turtles need to be surveyed for hemoparasites and helminths. Here we report new geographic and host records for a haemogregarine, a digene trematode and an acanthocephalan in map turtles, Graptemys spp. from the state.

On 25 May 2013, a juvenile Ouachita map turtle, Graptemys ouachitensis (carapace length $[\mathrm{cl}]=57 \mathrm{~mm}$, ASUMZ 33041) was collected by dipnet from the Lakeview Boat Dock, Baxter County $\left(36.370576^{\circ} \mathrm{N}\right.$, $\left.92.554544^{\circ} \mathrm{W}\right)$. On 25 July 2013, an adult male common map turtle, Graptemys geographica $(\mathrm{cl}=125$ $\mathrm{mm}$, ASUMZ 33042) was collected by hand from Crooked Creek, Marion County $\left(36.245225^{\circ} \mathrm{N}\right.$, $\left.92.715755^{\circ} \mathrm{W}\right)$. Both turtles were killed with an intraperitoneal injection of concentrated Chloretone and their plastrons were removed with a bone saw to expose visceral contents. Thin smears were made of blood samples taken from the heart, fixed in absolute methanol, stained with Wright's stain, rinsed in neutral buffer and examined by light microscopy for hematozoa. The entire gastrointestinal tract from the cloaca to esophagus and urinary bladder was removed, washed in $0.6 \% \mathrm{w} / \mathrm{v}$ saline, split longitudinally, and examined for helminths under a stereomicroscope. Trematodes were stained with acetocarmine and mounted in Canada balsam. Acanthocephalans were placed on slides with a drop of glycerol and studied as temporary mounts. Voucher specimens of hosts are deposited in the Arkansas State University Museum of Zoology (ASUMZ) Herpetological Collection, State University. Voucher specimens of parasites were deposited in the United States National Parasite Collection, Beltsville, Maryland. Scientific and common names of turtles follow the TIGR Reptile Database (Uetz and Hošek 2013).

A digene trematode was found in the $G$. ouachitensis while a haemogregarine and an acanthocephalan were recovered from the $G$. geographica. Data is presented below in annotated format.

\section{Apicomplexa: Adeleorina: Haemogregarinidae}

Haemogregarina sp. Danilewsky, 1885 - About $2 \%$ of the red blood cells of G. geographica contained an intraerythrocytic hematozoan thought to belong to the genus Haemogregarina (USNPC 107976). Banana-shaped immature gamonts were most often observed (Fig. 1). They were very similar to the "type IV" morphological type reported from Lonoke County T. s. elegans by McAllister and King (1980). McAllister et al. (1995, Fig. 3) also reported large immature gamonts from $M$. temminckii from Ouachita County similar of those from G. geographica. In addition, Acholonu (1974) reported Haemogregarina pseudemydis in Mississippi map turtle, Graptemys pseudogeographic kohnii (syn. Graptemys kohnii) from Louisiana. Haemogregarines are most commonly reported from aquatic turtles with leeches serving as the only known invertebrate hosts and vectors (Telford 2009). We document a new host record for a haemogregarine in G. geographica.

\section{Journal of the Arkansas Academy of Science, Vol. 68, 2014}




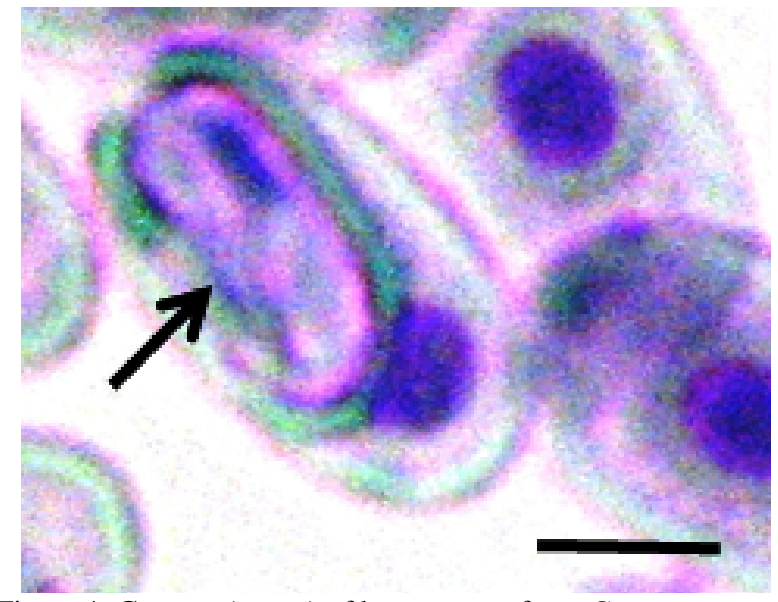

Figure 1. Gamont (arrow) of hematozoan from Graptemys geographica. Scale bar $=10 \mu \mathrm{m}$.

\section{Trematoda: Digenea: Plagiorchiida: Telorchiidae}

Telorchis attenuata Goldberger, 1911 - Numerous (> 100) digene specimens fitting the description of $T$. attenuata (Fig. 2, USNPC 107963) and confirmed using the key to North American species of Telorchis provided by MacDonald and Brooks (1989) were found in the intestine of $G$. ouachitensis. This trematode was previously reported in common snapping turtles, Chelydra serpentina from Ohio (Rausch 1947) and painted turtles, Chrysemys picta from Indiana (Goldberger 1911), Iowa, Maryland (MacDonald and Brooks 1989), Michigan (Esch and Gibbons 1967), Nebraska (Brooks and Mayes 1975), Ohio (Rausch 1947, Platt 1977), Wisconsin (Guilford1959) and British Columbia, Canada (MacDonald and Brooks 1989), and T. scripta from Mexico (Moravec and Vargas-Vásquez. 1998) and Spain (Cardells et al. 2013). Previously in the state,

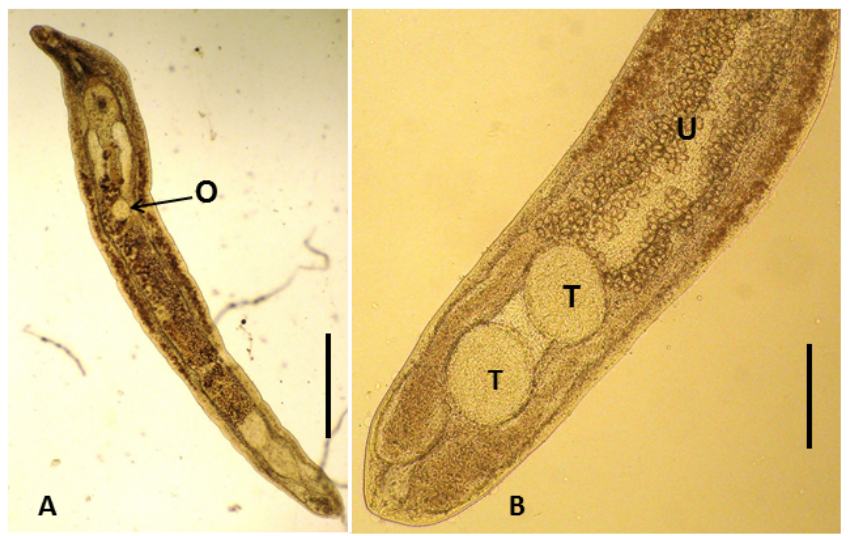

Figure 2. Telorchis attenuata (unstained) from Graptemys geographica. (A) Entire worm showing ovary (O); scale bar $=100$ $\mu \mathrm{m}$. (B) Lower half of worm showing tandem testes (T) and uterus (U) with ova; scale bar $=25 \mu \mathrm{m}$.
Rosen and Manis (1976) reported Telorchis stunkardi Chandler, 1923 from the three-toed amphiuma, Amphiuma tridactylium and Rosen and Marquardt (1978) reported Telorchis corti Stunkard, 1915 and Telorchis singularis (Bennett, 1935) Wharton, 1940 from T. scripta from Lake Conway (see MacDonald and Brooks 1989). Brooks and Mayes (1976) previously reported Telorchis chelopi MacCallum, 1919 (syn. Telorchis gutturosi Brooks and Mayes, 1976) from false map turtle, Graptemys pseudogeographica pseudogeographica from Nebraska. We document a new host and new geographic record for T. attenuata.

\section{Acanthocephala: \\ Eoacanthocephala: \\ Neoechinorhychida: Neoechinorhynchidae}

Neoechinorhynchus emydis (Leidy, 1851) Van Cleave, 1916 - Of the acanthocephalans we examined from the intestinal tract of $G$. geographica that included immatures and both sexes, every gravid female (USNPC 107211) represented N. emydis (Fig. 3 ), confirmed by the anatomy of the eggs and posterior ends (Barger and Nickol 2004). There were more than 200 individual worms in this host (Fig. 3A). Previous hosts of $N$. emydis include $G$. geographica, G. pseudogeographica, Texas map turtle, Graptemys

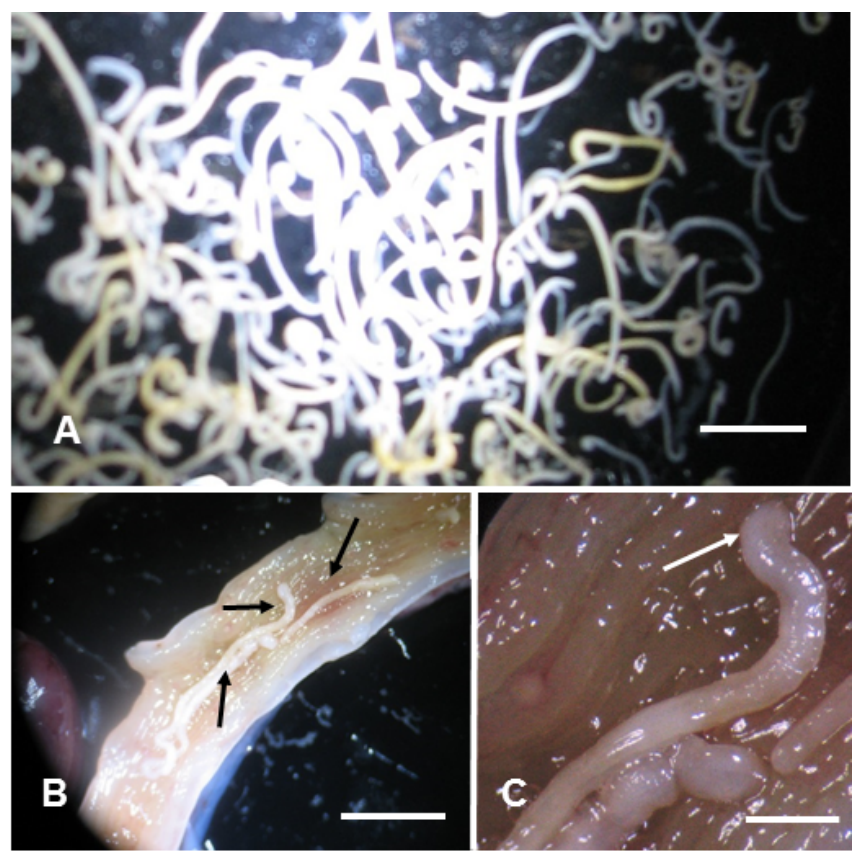

Figure 3. Neoechinorhynchus emydis. A. Gross view of acanthocephalans removed from intestinal tract showing intensity of infection. Scale bar $=1 \mathrm{~mm}$. B. In situ view showing three worms in intestine (arrows). Scale bar $=10 \mathrm{~mm}$. C. Closer view of worm with proboscis embedded in intestinal mucosa (arrow). Scale bar $=2 \mathrm{~mm}$. 
versa, C. serpentina, river cooter, Pseudemys concinna, T. scripta, spotted turtle, Clemmys guttata, wood turtle, Glyptemys insulpta, and Blanding's turtle, Emydoidea blandingii (Hopp 1954, Ernst and Ernst 1977, Barger 2004). This acanthocephalan has been reported most often from the eastern half of the upper Mississippi River drainage, including Illinois, Indiana, Mississippi, Ohio, Oklahoma and Texas (Williams 1953, Everhart 1958, Barger 2004), and now Arkansas. In addition, Rosen and Marquardt (1978) reported four species of Neoechinorhynchus (but not N. emydis) from $T$. s. elegans from the state. Thus, we document a new distributional record for $N$. emydis in the Arkansas.

Turtles are hosts of numerous described and undescribed hematozoans and helminths (Ernst and Ernst 1977, 1979, Telford 2009). Because Arkansas supports 19 species and subspecies of turtles within four families (Trauth et al. 2004), we suggest additional surveys on larger samples of turtles from the state as several species remain to be examined for hematozoans and endoparasites. The inclusion of DNA sequence analysis would be particularly helpful to identify some parasite species which have limited morphological traits (i.e., haemogregarines). As such, we predict additional new host and distributional records, including the possibility of discovery of new species.

We thank P.R. Pilitt (USNPC) and Dr. S.E. Trauth (ASUMZ) for expert curatorial assistance. The Arkansas Game \& Fish Commission provided Scientific Collecting Permits to CTM and MBC.

\section{Literature Cited}

Acholonu AD. 1974. Haemogregarina pseudemydis n. sp. (Apicomplexa: Haemogregarinidae) and Pirhemocyton chelonarum n. sp. in turtles from Louisiana. Journal of Protozoology 21:659-664.

Barger MA. 2004. The Neoechinorhynchus of turtles: Specimen base, distribution, and host use. Comparative Parasitology 71:118-129.

Barger MA and BB Nickol. 2004. A key to the species of Neoechinorhynchus (Acanthocephala: Neoechinorhynchidae) from turtles. Comparative Parasitology 71:4-8.

Brooks DL and MA Mayes. 1975. Platyhelminths of Nebraska turtles with descriptions of two new species of spirorchiids (Trematoda: Spirorchiidae). Journal of Parasitology 61:403-406.
Brooks DL and MA Mayes. 1976. Telorchis gutturosi sp. n. (Trematoda: Telorchiidae) from Graptemys pseudogeographica Gray in Nebraska, with reports of additional species of trematodes from Nebraska turtles. Journal of Parasitology 62:901-905.

Cable RM and FM Fisher Jr. 1957. A fourth species of Neoechinorhynchus (Acanthocephala) in turtles in the United States. Journal of Parasitology (Suppl.) 43:29.

Cardells J, MM Garijo, C Marín and S Vega. 2013. Helminths from the red-eared slider Trachemys scripta elegans (Chelonia: Emydidae) in marshes from the eastern Iberian Peninsula: First report of Telorchis attenuata (Digenea: Telorchiidae). Basic and Applied Herpetology 27: online first: http://dx.doi.org/10.11160/bah.12006.

Ernst EM and CH Ernst. 1977. Synopsis of helminths endoparasitic in native turtles of the United States. Bulletin of the Maryland Herpetological Society 13:1-75.

Ernst EM and CH Ernst. 1979. Synopsis of protozoans in native turtles of the United States. Bulletin of the Maryland Herpetological Society 15:1-15.

Esch GW and JW Gibbons. 1967. Seasonal incidence of parasitism in the painted turtle, Chrysemys picta marginata Agassiz. Journal of Parasitology 53:818-821.

Everhart BA. 1958. Notes on the helminths of Pseudemys scripta elegans (Wied, 1838) in areas of Texas and Oklahoma. Proceedings of the Oklahoma Academy of Science 38:38-43.

Fisher FM Jr. 1960. On Acanthocephala of turtles, with the description of Neoechinorhynchus emyditoides n. sp. Journal of Parasitology 46:257266.

Goldberger J. 1911. On some new parasitic trematode worms of the genus Telorchis. Hygiene Lab Bulletin 71:36-47.

Guilford HG. 1959. Some helminth parasites found in turtles from northeastern Wisconsin. Transactions of the Wisconsin Academy of Sciences, Arts, and Letters 48:121-124.

Hopp WB. 1954. Studies on the morphology and life cycle of Neoechinorhynchus emydis (Leidy), an acanthocephalan parasite of the map turtle, Graptemys geographica (Le Sueur). Journal of Parasitology 40:284-299. 
MacDonald CA and DR Brooks. 1989. Revision and phylogenetic analysis of the North American species of Telorchis Luehe, 1899 (Cercomeria: Trematoda: Digenea: Telorchiidae). Canadian Journal of Zoology 67:2301-2320.

McAllister CT and AW King. 1980. Hemogregarines in the red-eared slider, Chrysemys scripta elegans (Wied) from Arkansas. Proceedings of the Arkansas Academy of Science 34:124.

McAllister CT, SJ Upton, and SE Trauth. 1995. Hemogregarines (Apicomplexa) and Falcaustra chelydrae (Nematoda) in an alligator snapping turtle, Macroclemmys temminckii (Reptilia: Testudines), from Arkansas. Journal of the Helminthological Society of Washington 62:70-73.

Moravec F and J Vargas-Vásquez. 1998. Some endohelminths from the freshwater turtle Trachemys scripta from Yucatan, Mexico. Journal of Natural History 32:455-468.

Platt TR. 1977. A survey of the helminth fauna of two turtle species from northwestern Ohio. Ohio Journal of Science 77:97-98.

Rausch R. 1947. Observations on some helminths parasitic in Ohio turtles. American Midland Naturalist 38:434-442.

Rosen R and R Manis. 1976. Trematodes of Arkansas amphibians. Journal of Parasitology 62:833-834.

Rosen R and WC Marquardt. 1978. Helminth parasites of the red-eared turtle (Pseudemys scripta elegans) in central Arkansas. Journal of Parasitology 64:1148-1149.

Telford SR Jr. 2009. Hemoparasites of the Reptilia: Color guide and text. Boca Raton (FL): CRC Press. $276 \mathrm{p}$.

Trauth SE, HW Robison and M Plummer. 2004. The amphibians and reptiles of Arkansas. Fayetteville (AR): University of Arkansas Press. $421 \mathrm{p}$.

Uetz $\mathbf{P}$ and J Hošek. 2013. The TIGR Reptile Database. World Wide Web electronic publication. http://www.reptile-database.org/. Accessed 26 December 2013.

Ward HB and SH Hopkins. 1931. A new North American aspidogastrid, Lophotaspis interiora. Journal of Parasitology 18:69-78.

Williams RW. 1953. Helminths of the snapping turtle, Chelydra serpentina, from Oklahoma, including the first report and description of the male of Capillaria serpentina Harwood, 1932. Transactions of the American Microscopical Society 72:175-178. 